Dept. of Vet. Medicine,

Fac. of Vet. Med. Suez Canal Univ.

\title{
SOME STUDIES ON CLINICAL, HEMATOLOGICAL AND BIOCHEMICAL CHANGES IN DIARRHOEIC NEONATAL BUFFALO CALVES WITH REFERENCE TO HYGIENIC CONDITIONS
}

(With 4 Tables)

\section{By}

\section{ASMA O. ALY ; ZAMZAM H. ABD EL-WAHED*; KH. KOHILO ** and A. R. EL-SHEIKH *** \\ * Dept. of vet. Hygiene, Fac of Vet. Med., Suez Canal Univ. ** Dept. of Biochemistry, Fac. Vet. Med., kafr El-sheikh. *** Dept. of Vet. Med., Fac. Vet. Med., Zagazig Univ.}

(Received at 9/3/1996)

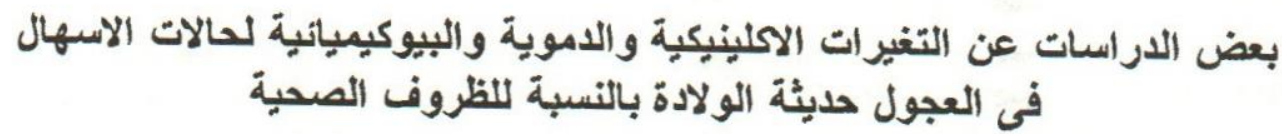
أسعاء على ، زمزم عبد الواحد ، خالد كمبيو، عبل الخالت الشبن

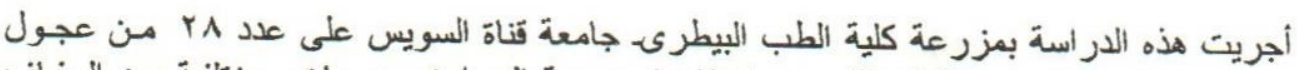

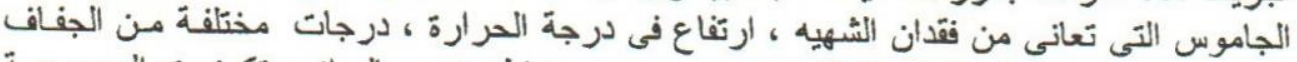

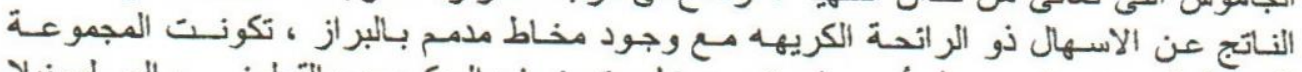

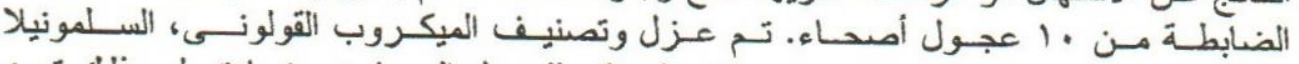

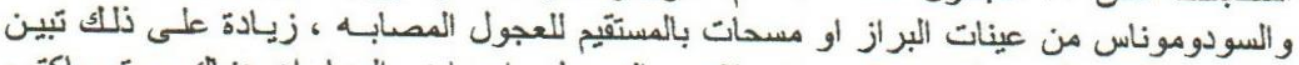

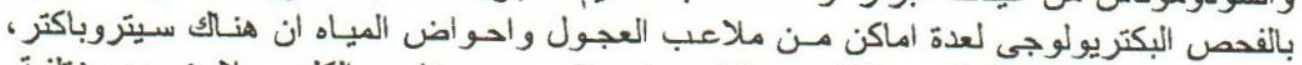

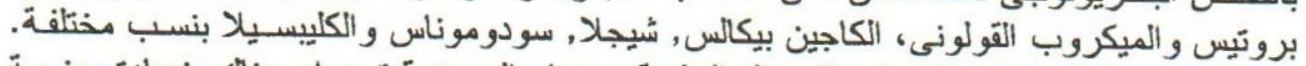

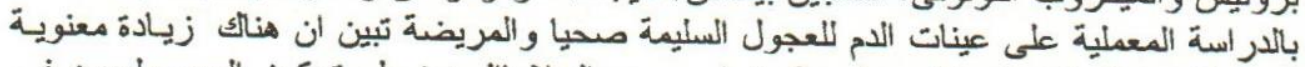

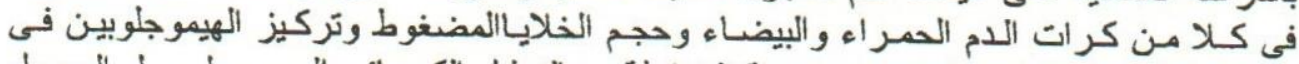

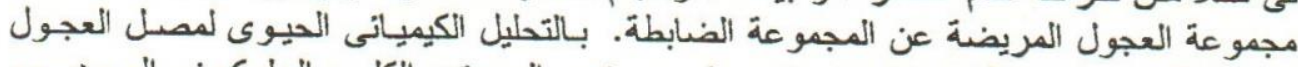

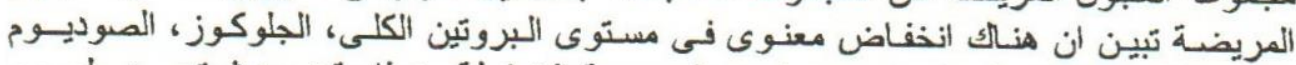

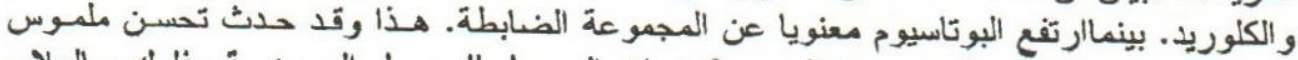

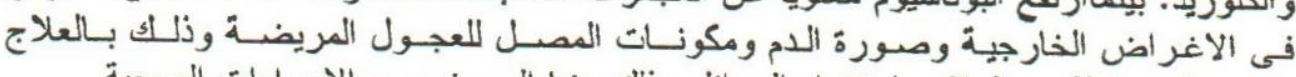

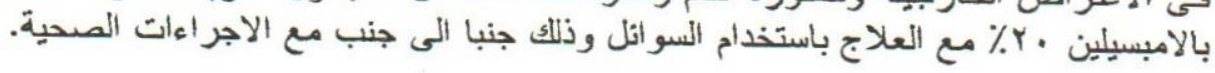




\section{SUMMARY}

This study was carried out on 28 diseased buffalo calves suffered from anorexia, elevation in body temperature, depression with varying degrees of dehydration and diarrhoea with offensive odour and bloody mucoid discharge. Other ten clinically healthy buffalo calves served as control group were also included. These calves were belonging to the farm of faculty of Veterinary Medicine, Suez Canal University. Enteropathogenic E. coli (12 isolates), Salmonella sp. (5 isolates) and Pseudomonas sp. (8 isolates) were recovered and identified from diseased rectal samples and incriminated as the causative agent of diarrhoeic neonatal calves. Bacteriological examination of different locations of calve's yard soil and water troughs was carried. This examination revealed the presence of E coli, Proteus sp., Citrobacter sp., Klebsiella sp., Pseudomonas sp., Shigella sp., and Alcaligens feacalis in different percentages. The hematological study was conducted on blood samples of apparently healthy and diseased calves showed significant increase in both total erythrocytic and leucocytic count, packed cell volume and haemoglobin concentration in diarrhoeic calves versus to the control ones. Blood serum biochemical analysis revealed significant decrease in the level of total protein, glucose, sodium and chloride, while blood serum potassium level was significantly increased in diarrhoeic calves than in control ones. Excellent improvement in clinical symptoms, blood picture and blood serum constituents were observed following treatment with ampicillin $20 \%$ in combination with fluid therapy and application of good sanitary measures.

Key words: Biochemical changes-diarrhoeic buffalo-calves.

\section{INTRODUCTION}

Diarrhoea is still one of the most important causes of calf mortality and morbidity that lead to severe economic losses. The incidence of diarrhoeal diseases in neonatal calves increased in the recent years depending on the sanitary and hygienic managements (ABD EL-HAMID, 1977).

Regarding the most common basic causes of diarrhoea, a lot of work had been done of which enterotoxogenic E. coli, Salmonella species and Clostridium (TENNANT et al., 1972; ABS EL-HAMID, 1977; AMER et $\underline{\text { al. }}$, 1985; SNODGRASS et al., 1986 and FARID $\underline{\text { et }}$ al., 1992). 
Diarrhoea in young pre-weaned calves causes remarkable disturbances in

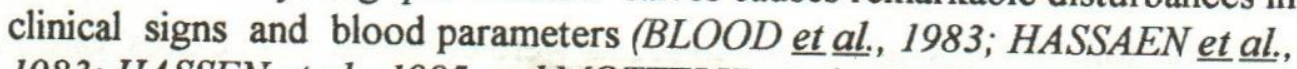
1983; HASSEN $\underline{\text { et }}$ al., 1985 and MOTTELIB $\underline{\text { t }} \underline{\text { al. }}$., 1992).

The undue use of antibiotics in veterinary medicine constitutes a public health (hazard by development of super-resistant bacteria (BERCHNEIDER \& ARGENZIO, 1983).

The present investigation was designed ot study the aetiological agents causing diarrhoea in neonatal buffalo-calves and their sensitivity to various antibiotics. Moreover, the study included some haematological and biochemical alterations in response to enteric diseases as well as to determine the effectiveness of specific antibacterial agents. Also the role of water and soil hygiene in developing and existence of diarrhoeic agents was considered.

\section{MATERIAL and METHODS}

This work was carried out on 38 buffalo-calves belonging to the Farm of Faculty of Veterinary Medicine, Suez Canal University. Among these animals, 28calves showed signs of diarrhoea, while 10 clinicaly normal ones served as control. The age of these buffalo-calves ranged between 2-4 weeks, and their weights Varied from $35-44 \mathrm{~kg}$. The animals were kept free in an open yard, watered freely, and fed on natural suckling. Both diseased and control buffalo-calves were subjected to clinical examination.

Form each animal, two rectal faecal samples were collected before and at the seventh day after treatment. The first sample was taken directly from the rectum using sterile swab for bacteriological examination (WILSON \& MILES, 1984), while the second faecal sample was taken in plastic bag for parasitological studies (COLES, 1980).

The antibiotic sensitivity test of different isolated microorganisms against various antibacterial agents was carried out using disc method reported by GOULD \& BOWIE (1952).

Two blood samples were collected from both control and diseased groups just before seven days post treatment. The first blood sample was taken in tubes containing anticoagulant (heparin concentration of $0.1 \mathrm{mg} / \mathrm{ml}$. blood) used for determination of both total erythocytic and leucocytic counts per $\mathrm{mm}^{3}$, packed cell volume (SCHALM, 1975) and haemoglobin (VAN$K A M P E N, 1961)$. The second blood sample was used for obtaining clear serum to determine total protein, glucose, and chloride according to King and Wotton (1959) and WERNER et al. (1970) respectively. Sodium and 
potassium levels were analysed on a flame photometer according to the method of OSER (1965).

Forty soil samples each of 100 grams were collected from calves' yard in sterile screw-capped bottles. Twenty samples of them were collected from different areas of the yard already exposed to sun-rays, while the other twenty soil samples were collected from areas under yards shed. All soil samples were examined physically according to CRUICKSHANK et $\underline{\text { al }}$. (1975) to determine $\mathrm{pH}$ and moisture content. The temperature of soil samples was recorded at time of sampling using Beckmann thermometer. Meanwhile, bacteriological examination of these samples was done after MERCHANT \& PACKAR (1977).

From watering trough, 50 water samples were obtained for physical analysis to determine $\mathrm{pH}$ and temperatue at time of sampling. Bacteriological examination were also done (EDWARD and EWING, 1972).

The diseased calves were isolated and watered separately from special buckets which were thoroughly washed and disinfected before use. The superficial layer of $10 \mathrm{~cm}$ yard's soil was removed and replaced by new uncontaminated soil as well as periodical continuous turn-over with Quick lime ( 2 tons/acre) was tried.

Chemotherapeutic trial was done by using Ampicillin 20\% at a dose rate of $20 \mathrm{mg} / \mathrm{kg} \mathrm{B}$.w. $/ 12$ hours (in the form of powder dissolved in $10 \mathrm{ml}$ of distilled water and given orally using drenching gun) for five successive days. Moreover, oral fluid replacement therapy according to BLOOD $\underline{\text { t }} \underline{\text { al. }}$, (1983) at rate of $100-\mathrm{ml} / \mathrm{kg}$ body weight in eight divided doses was tried as follows:Oral electrolyte formula (BLOOD $\underline{\text { t }} \underline{\text { al. }}$, 1983).

Sodium chloride,

Potassium chloride,

Sodium bicarbonate,

Potassium phosphate,

Total
$117 \mathrm{~g}$.

$150 \mathrm{~g}$.

$168 \mathrm{~g}$.

For $1000 \mathrm{ml}$ of oral solution, add $5.7 \mathrm{~g}$. of dry mixture, to which also $50 \mathrm{~g}$. of glucose was added.

The obtained data were statistically analysed according to SNEDECOR and COCHRAN (1969). 


\section{RESULTS}

The clinical signs obseved on the diseased buffalo-calves from diarrhoea revealed that most of the cases showed loss of appetie, fever $\left(40.7-41.8^{\circ} \mathrm{C}\right)$ that decreased just after the onset of diarrhoea, depression, increase in pulse and respiratory rates profuse diarrhoea with offensive odour accompanied with mucoid and/or bloody discharge. The hind-limbs were splashed with faeces and also varying degrees of dehydration were observed.

The results of bacteriological examination of rectal faecal swabs obtained from apparently normal buffalo-calves as well as the diseased ones are shown in table (1).E. coli was the most important organism incriminated as the causative agent of diarrhoea in pre-weaned calves. E. coli which showed agglutination with anti K99 serum standard was considered as enteropathogenic E. coli. The other obtained faecal bacterial isolates were represented by Salmonella sp. and Pseudomonas sp.

As shown table (2) revealed that the causative bacterial isolates were sensitive mainly to ampicillin $20 \%$. On the other hand, parasitological examination of faecal samples revealed negative results.

The results of physcial and bacteriological examinations of soil samples from calves, yard under different circumstanses as well as water samples are shown in table (3). The physical examination of soil revealed that high moisture content (5.0-5.7\%), $\mathrm{pH}$ value (7.0-7.5) and temperature (37.5$38^{\circ} \mathrm{C}$ ) in shadow locations, while in sunny ones moisture content, $\mathrm{pH}$ and temperature were $1.0-1.5 \%, 6.7 \& 38.5-39$, respectively. Bacteriological examination of soil (under shadow) and water saamples revealed that most isolates related to family Enterobacteriaceae.

Results of blood examination (RBCs, WBCs, $\mathrm{Hb}$ and $\mathrm{PCV}$ ) of clinical normal calves and those suffering from diarrhoea just before and seven days after the onset of treatment (Table. 4) revealed highly significant $(\mathrm{P}<0.001)$ increase in erythrocytic count, packed cell volume and total leucocytic count. Also a significant $(\mathrm{P}<0.01)$ increase in haemoglobin concentration in diarrhoeic calves in comparison with apparently healthy ones. Regarding serum biochemical analysis, (Table. 5) the obtained results showed a highly significant $(P<0.001)$ increase in total protein, a highly significant $(P<0.001)$ decrease in serum glucose, sodium and chloride levels with a significant $(\mathrm{P}<0.05)$ increase in serum potassium level in diarrhoeic calves aganist control group.

The clinical response was noticed on the treated calves at the second to third day of treatment, while good clinical improvement was completely 


\section{DIARRHOEIC BUFFALO CALVES AND HYGIENE}

observed at the fourth to fifth day of treatment, while seven days post treatment haemoglobin and biochemical values were within normal values.

\section{DISCUSSION}

The most important cause of economic losses in beef industries is the infectious neonatal diarrhoea (BLOOD $\underline{\text { et }} \underline{\text { al., }}$ 1983). Bacteriological examination of diseased calves in our study revealed that the enteropathogenic $\mathrm{E}$. coli was the most prevalent organism representing $66.6 \%$, Salmonella sp. $27.7 \%$ and Pseudomonas sp. $44.4 \%$. These results agreed with the findings of TZIPORI, (1981) and FARID (1992). The production of enterotoxin by E.coli stimulates mucosal adenyl cyclase activity that leads to increase cyclic adenosine monophosphate (AMP) which in turn increases the intestinal fluid secretion from the systemic circulation resulting in varying degree of dehydration, electrolyte imbalance and acidosis (BLOOD et al., 1983). Moreover, Salmonella sp. infection causes severe mucosal damage and increases permeability of the mucosal epithelium that result in uncontrolled leakage of water and ions into the intestinal lumen (ROBINSON \& HUXTABLE, 1988). BLOOD $\underline{\text { et }}$ al. 1983) elucidated that sporadic cases of bovine salmonellosis may occur when animals are exposed to stress.

Physical examination of soil samples were taken from sunny locations revealed lower levels of moisture content, $\mathrm{pH}$ and temperature than that of shadow locations. These results coincided with those of $A B D E L-K A R I M$, (1968), ABD EL-HAMID \& ZAKI, (1972) and ABD EL-KARIM et al., (1977) who attributed these variations to adverse environmental conditions.

Bacteriological findings of soil samples collected from the under shed were E.coli $100 \%$, Proteus sp. $70 \%$, Citobacter sp. $23 \%$, Kellebsiella sp. $10 \%$ Pseudomonas sp. $11 \%$, and Shigella sp. $12 \%$ and Alcaligenos faecalis $12 \%$, while from sunny locations were $70,20,8,9,6$ and $10 \%$, respectively). The obtained data reflected the lack of hygienic measures in such yard and agreed with those of $A B D$ EL-KARIM (1968).

Bacteriological examination of water samples showed the presence of family Enterobacteriaceae. The presence of such family in water is considered as an index of undesirable pollution as well as an indicator of faecal pollution (W.H.O. 1985), Isolation of E. coli 75\%, Proteus sp. $62 \%$, Citrobacter sp. $40 \%$, Kellbsiella sp. $73 \%$, Pseudomonas sp. $12 \%$ and Shigella sp. $14 \%$ from samples of water troughs was in agreement with MOUSTAFA et al., (1977) and EL-OLEMY $\underline{\text { et }} \underline{\text { al., }}$, (1989). 


\section{Assiut Vet. Med. J. Vol. 35 No. 69, April 1996.}

Bacteriological examination of faecal swabs, soil and water samples revealed that the most predomenant micro-organism responsible for the presence of diarrhoea in buffalo calves was the enteropathogenic E. coli. There is relationship between the environmental temp. R.H. and the incidence of those entropathogenic E. coli. This result coincided with that reported by $D E B O R A H$, (1972).

Haematological picture is widely used in veterinary medicine to evaluate the general health condition, diagnosis of some diseases (FREEDLLAND and NAMER, 1970). In diarrhoeic calves there was a highly significant $(\mathrm{P}<0.001)$ increase in erthrocytic count and packed cell volume $(10.206 \pm 0.205 \mathrm{x}$ $\left.10^{6} / \mathrm{mm}^{3} \& 34.833 \pm 0.439 \%\right)$ when compared with apparently healthy ones $\left(7.806 \pm 0.124 \times 10^{6} / \mathrm{mm}^{3} \& 27.90 \pm 0.537 \%\right)$, respectively. A significant $(\mathrm{P}<0.01)$ increase in haemoglobin concentrathion was observed in diseased animals $(12.288 \pm 0.237 \mathrm{gm} \%)$ against control ones $(10.450 \pm 0.215 \mathrm{gm} \%)$. These elevations in haemogram values were due to loss of body fluid caused by diarrhoea (BLOOD $\underline{\text { et }} \underline{\text { al., }}$ 1983). Moreover, highly significant increase $(\mathrm{P}<0.001)$ leucocytosis was observed in diseased calves $(14.166 \pm 0.240 \mathrm{x}$ $\left.10^{3} / \mathrm{mm}^{3}\right)$ versus to $\left(8.172 \pm 0.192 \times 10^{3} / \mathrm{mm}^{3}\right)$ in apparently healthy ones. This finding concided with DALTON $\underline{\text { et }} \underline{a l}$., 1965; AMER $\underline{e t} \underline{\text { al. }}$, 1985 and MOTTELIB et al., 1992. The markked increase in leucocytic count is due to bacterial infections and inflammatory lesions which acted promptly causing greater rise in total leucocytic count and more production of mature and immature neutrophils (DOXEY, 1983).

Blood serum biochemical analysis revealed a highly significant $(\mathrm{P}<0.001)$ increase in total proteins in diarrhoeic calves $(7.555 \pm 0.065 \mathrm{mg} \%)$ in comparison with clinically normal ones $(6.950 \pm 0.076 \mathrm{mg} \%)$. The hyperproteinemia in calves with enteritis due to E.coli and Salmonella infection may be due to the excessive loss of body fluids and concentration of some blood constituents especially in case of dehydration MANAA $\underline{\text { et }} \underline{\text { al }}$., 1993).

Highly significant $(\mathrm{P}<0.001)$ decrease in the level of glucose $(47.555 \pm$ $0.573 \mathrm{mg} \%)$ in serum of diarrhoeic calves compared with clinically healthy ones $(70.40 \pm 1.087 \mathrm{mg} \%)$ was observed. This result is in close agreement with that reported by MOTTELIB (1972) and Hassan et al., (1985) who attributed hypoglycaemia in Escherichia coli enteritis in buffalo calves to the alteration in tissue metabolism caused by decreased blood flow and oxygenation, while COLES, (1980) elucidated that hypoglycemia in case of enteritis may be due to lack in intestinal absorption. 
The obtained result showed a highly significant decrease $(\mathrm{P}<0.001)$ of serum sodium (126.833 $241 \pm 0.927 \mathrm{mEg} / \mathrm{L})$ and chloride $(87.22 \pm 0.946$ $\mathrm{mg} / \mathrm{L}$ ) in diarrhoeic calves in comparison with clinically normal ones $(139.310 \pm 0.735 \mathrm{mEg} / \mathrm{L} \& 100.40 \pm 0.98 \mathrm{mg} / \mathrm{L}$, respectively). Our findings coincided with that obtained by HASSAN $\underline{\text { t }} \underline{\text { al }}$ (1985) and RAGAB et al., (1986), who attributed hyponatremia and hypochloremia in diarhoeic calves to direct loss of sodium and chloride ion via faeces. On the other hand, potassium level in serum of diseased buffalo calves $(5.355+0.152 \mathrm{mEq} / \mathrm{L})$ increased significantly $(P<0.05)$ than its level in apparently normal ones $(4.90+0.53 \mathrm{mEq} / \mathrm{L})$. This finding was in agreement with ROUSSAL, (1983), HASSAN et al., (1985) and RAGAB et al., (1986). Diarrhoea is a common cause of metabolic acidosis due to direct loss of bicarbonate via faeces (LEWIS \& PHILLIPS, $1972 \&$ RAGAB et al., 1986) and therefore, during diarrhoea the increase of hydrogen ions are buffered by intracellular and extracellular buffers. In exchange for the intracellular movement of $\mathrm{H}^{+}, \mathrm{K}^{+}$ enters the extracellular compartment predisposing to hyperkalemia (RABINSON \& HUXTABLE, 1988).

About chemotherapeutic treatment noticeable clinical improvements were observed following administration of specific antibacterial agent in addition to fluid therapy on the third to fourth day of treatment accompained with good hygienic measures in soil and water troughs. Moreover, all the disturbed blood parameters were corrected and returned nearly to normal levels at the seventh day of treatment.

From this study, it could be concluded that bacterial calf diarrhoea is responsible for causing remarkable disturbances in haematological and biochemical values through direct and indirect effects due to impaired defence mechanisms. This by turn reflects the disturbance in general health condition of the affected calves. So attention must be paid for careful early clinical and laboratory diagnosis of diseased calves followed by the use of specific antibiotics accompanied by fluid replacement therapy. Finally, and as it is always said, prevention is better than cure, good management of calves from time of birth and untill weaning is the key factor in protection them during this critical period of their lives.

\section{REFERENCES}

Abd El -Hamid, Y.M. and Zaki, M.M. (1972): Viability of corynebacterium ovis in animal dewellings in different seasons. 
Abd El-Karim (1968): The incidence of animal infections in the soil of some animal dewelling. M.D. Vet. Hyg. Thesis, Fac. of Vet., Med. Cairo Univ.

Abd El-Karim, M.A. Miligy, M. and Hamed, M.O. (1977): Survival of some members of the corynebacteriaceae in the soil with special reference to the effect of some disinfectants used in vecterinary practice. Egyptian Vet. Med. J. XXIII (23).

Amer, A.A.; El-Sebaie, A. and Hassan, N.K. (1985): Studies on an outbreak of colibacillosis among newlyborn Holstein Friesian calves in the Newvally, Egypt. I- Clinical, Heamatological, Aetiological and pathological alterations. Assiut Vet. Med. J. 14, 27: 151-157.

Berschneider Helen M. and Argenzio A. Robert (1983):

pathophysiological approach to the treatment of infectious diarrhoea in the neonata calf \& pig.Iowa State Veterinarian, 4, 2.

Blood, D.C.; Radastits, O.M. and Handerson, J.A. (1983): "Veterinary Medicine", 6th Ed., Bailliere, Tindall.

Coles, E.H. (1980): Veterinary clinical pathology" 3rd, ed. W.B. saundres company, philadelphia, London.

Dalton, R.G.; Fisher, E.W. and McIntyre, W.I.M. (1965) Changes in blood chemistry, body weight and haematoctit of calves affected with neonatal diarrhoea." Brit. Vet. J. 121, 34.

Deborah, H. (1972): "Survey on mastitis caused by environmental bacteria" Vet. Rec., 90, 654-657.

Doxey, D.L. (1983): "Clinical pathology and diagnostic procedure" 2nd Ed. Bailliere Tindall, London.

Edwards, P.R. and Ewing, W.H. (1972): Identification of Enterobactericeae, 3 rd Ed., Burgess publishing Co., Muneapalis, Minnesotal U.S.A.

El-Olemy, G.M.; Aidarros, H.A. El-Bassiouni, A.A. and Mona, A. (1989):

"Hygienic quality of ground water sources used for animals in

Kalyobia Governorate "Assuit Vet. Med. J., 21, (41), 148-153.

Farid, F.A.; Kaldas, T.Y.; Soheir Sh.E.; Naeal Gh.K. and Saad, K.M. (1992): "Prevalence of Escherichia coli K99 in diarrhoeic newborn calves". Proc.5th Sci. Cong., Fac. Vet. Med., Assuit.

Freedland, R. and Kramer, J. (1970): Advances in veterinary science and comparative medicine "Vol. 14 Academic Press, New York and London, 51-105.

Gould, J.C. and Bawie, J.H. (1952): The use of impregnated filter discs for determinating the sensitivity of bacteria to antibiotics. Edib. Med. J., $59,178$. 
Cruickshank, R.; Duguid, J.P.; Marmion, B.P. and Swain, R.H. (1975): "Medical Microbiology, the Practice of Medical Microbiology", 17 th Ed. Vol. II London \& New York.

Hassaen, N.K.; El-Sebaie, A. and Amer, A.A. (1983): Studies on an outbreak of colibacillosis among Holstein Friesian calves in the Newvalley, Egypt. II- some serum biochemical and electrolyte changes. Assiut Vet. Med. J. 14 (27): 161-168.

King, E.J. and Woottin, I.D.P. (1959): "Micro-Analysis in Medical Biochemistry" Churchill, London.

Lewis, L.D. and Phillips, R.W. (1972): "Water and electrolyte cases in neonatal calves with acute diarrhea". A complete balance study Cornell Vet., 62, 596-607.

Manaa, A.M.; Sayed, A.M.; Thabet El-R.A. and Abd El-Fattah (1993): "Some microbial and blood biochemical studies on buffalo calves suffering from entiritis. Assiut Vet. Med. J. 29, (58), 144-153.

Mottelib, A.A. (1972): A study on the changes of blood in buffalo calves suffering from entiritis due to different causative agents "MVSC Thesis, Fac. Vet. Med. Assuit Univ. Egypt.

Mottelib, A.A.; Ammar, A.M. and Haroum, E.M. (1992): Some studies on entiritis in young lambs".J. Egypt. Vet. Ass. 52 No. 1, 1-11.

Mostafa, T.H.; Ismailia, A.A.; Ahmed, A.A. and Kamel, Y.Y. (1977):

"Microbiology evaluation of water supplies in different animals enclosure". Assuit Vet. Med. J., 4(1), 97-103.

Oser, B.L.: (1965): Hawk's physiological chemistry 14th Ed. McGraw-Hill Book Company New Relhi.

Ragab, A.M.; Agag, B.I.; Eid, M.A. and El-Danaf, N.A.A. (1986): Diarrhoece and dehydration in newly-born calves. Alex. J. Vet. Sci., 2(1), 499-508.

Robinsion, W.F. and Haxtable, C.R.R. (1988): Clinicopathologic principles for veterinary medicine. $1 \underline{\text { st }}$ Ed. Great Britian, Cambridge Univ. Press.

Roussel, A.J. (1983): The compendium on containing eduction, 5, (6), 332 (9).

Schalm, O.W. (1975): Veterinary haematology". 3rd Ed. Beiileke tindall and cow. London.

Snedecor, G.W. and Cochran, W. (1969): "Statistical Methods". 6th Ed. Iow State Univ. Press, Anes, Anes. Iowa U.S.A. 
Snodgrass, D.R.; Texzolo, H.R.; Sherwood, D.; Camphbell, I.; Menzies, J.D. and Synge, B.A. (1986): Aetiology of diarrhoea in young calves. Vet. Rec. 119 (12), 31-34.

Tennant, B.; Harrold, D. and Reina Guerra, M. (1972): Physiologic and metabolic factors in pathogenesis of neonatal entiric infections in calves. J.A.V.M.A. 161 (9).

Tzipori, S. (1981): The aetiology and diagnosis of calf diarrhoea Vet. Rec. $108,510-514$.

Vankampen, E.J. (1961): Colorimetric determination of haemoglobin, clin. Chem. Acta. 6: 538-544.

Werner, W.H.; Rey, G. and Wielinger (1970): Determination of glucose. Z. Analyt. Chem. 252-224.

Wilson, G.S. and Miles, A.A. (1984): Toply and Wilson's princples of bacteriology and immunity. 3rd Ed. Vol. 1. Edward Arnold and Co., London.

W.H.O. (1985): "International standard for drinking water". Palais de Narions, Geneva, 1985. 


\section{DIARRHOEIC BUFFALO CALVES AND HYGIENE}

Table (1): Shows the number and percentages of the organisms isolated from feacal swabs of apparently normal and diarrhoeic calves.

\begin{tabular}{|c|c|c|c|c|c|}
\hline $\begin{array}{c}\text { Type of } \\
\text { micro-organism }\end{array}$ & $\begin{array}{l}10 \text { apper } \\
\text { calves } \\
\text { No. of } \\
\text { isolates }\end{array}$ & $\%$ & $\begin{array}{l}18 \text { disea } \\
\text { No. of } \\
\text { isolates }\end{array}$ & $\begin{array}{l}\text { calves } \\
\%\end{array}$ & $\begin{array}{c}\text { Total } \\
\text { No. of isolates }\end{array}$ \\
\hline - Non pathogenic E. coli & 8 & 80 & 5 & 27.7 & 13 \\
\hline - Pathogenic E. coli & - & - & 12 & 66.6 & 12 \\
\hline - Salmonella sp. & - & - & 5 & 27.7 & 5 \\
\hline - Pseudomonas sp. & 4 & 40 & 8 & 44.4 & 12 \\
\hline Total number of isolates & 12 & & 30 & & 42 \\
\hline
\end{tabular}

Table (2): Shows results of sensitivity tests of isolates against different antimicrobial agents

\begin{tabular}{|l|c|c|c|c|}
\hline $\begin{array}{c}\text { Therapeutic agents } \\
\text { of antibiotic disc. }\end{array}$ & $\begin{array}{c}\text { Concentration } \\
\text { of disc }\end{array}$ & E. coli & $\begin{array}{c}\text { Salmonella } \\
\text { spp. }\end{array}$ & $\begin{array}{c}\text { Pscudomonas } \\
\text { spp. }\end{array}$ \\
\hline Tetracyclen & $30 \mu \mathrm{g}$ & $(-)$ & ++ & $(+)$ \\
Penicilline G. & $10 \mathrm{IU}$ & ++ & + & +++ \\
Ampicilline & $10 \mu \mathrm{g}$ & +++ & ++ & +++ \\
Colistin & $10 \mu \mathrm{g}$ & ++ & ++ \\
Neomycin & $30 \mu \mathrm{g}$ & + & ++ & ++ \\
Erythromycin & $15 \mu \mathrm{g}$ & ++ & $(-)$ & + \\
\hline
\end{tabular}


Assiut Vet. Med. J. Vol. 35 No. 69. April 1996.

\begin{tabular}{|c|c|c|c|c|}
\hline \multirow{4}{*}{ 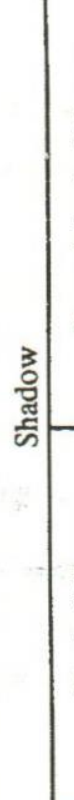 } & 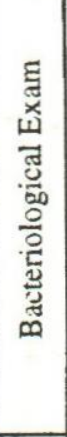 & 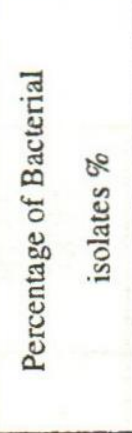 & 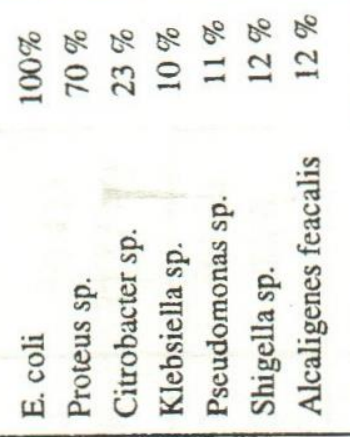 & 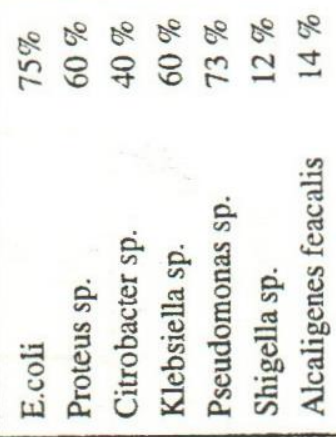 \\
\hline & \multirow{3}{*}{ 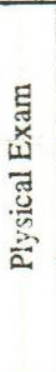 } & 灾 & $\begin{array}{l}\text { co } \\
\text { ñ } \\
\text { ñ } \\
\text { ch }\end{array}$ & 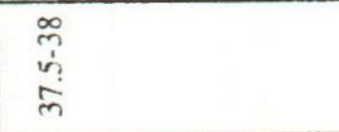 \\
\hline & & 㟥苛。o & $\begin{array}{l}\text { r. } \\
\text { o. } \\
\dot{n}\end{array}$ & \\
\hline & & $\dot{I}$ & $\begin{array}{l}\frac{n}{3} \\
\frac{1}{r}\end{array}$ & $\begin{array}{l}m \\
\stackrel{m}{0} \\
\dot{\infty} \\
\dot{b}\end{array}$ \\
\hline \multirow{4}{*}{$\begin{array}{l}\text { s. } \\
\text { : } \\
\text { n }\end{array}$} & 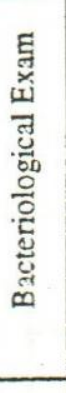 & 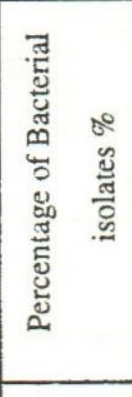 & 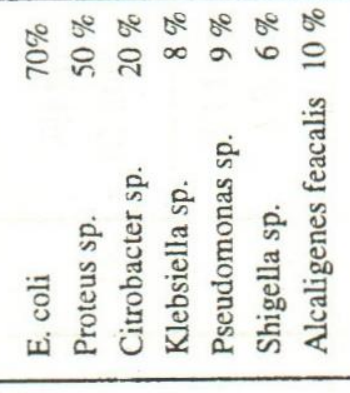 & \\
\hline & \multirow{3}{*}{ 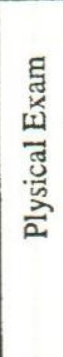 } & 突 & $\begin{array}{l}\text { ले } \\
\hat{n} \\
\infty \\
\text { n}\end{array}$ & \\
\hline & & 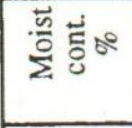 & $\frac{n}{b}$ & \\
\hline & & 覀 & $\frac{0}{\frac{1}{1}}$ & \\
\hline \multicolumn{3}{|c|}{ 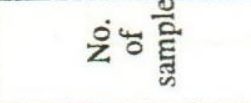 } & q & in \\
\hline \multicolumn{3}{|c|}{ 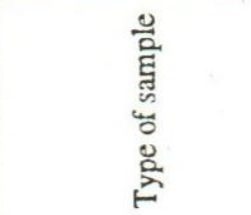 } & 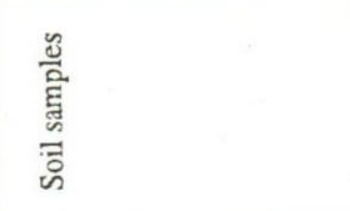 & 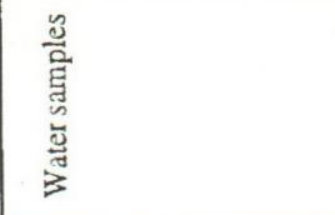 \\
\hline
\end{tabular}




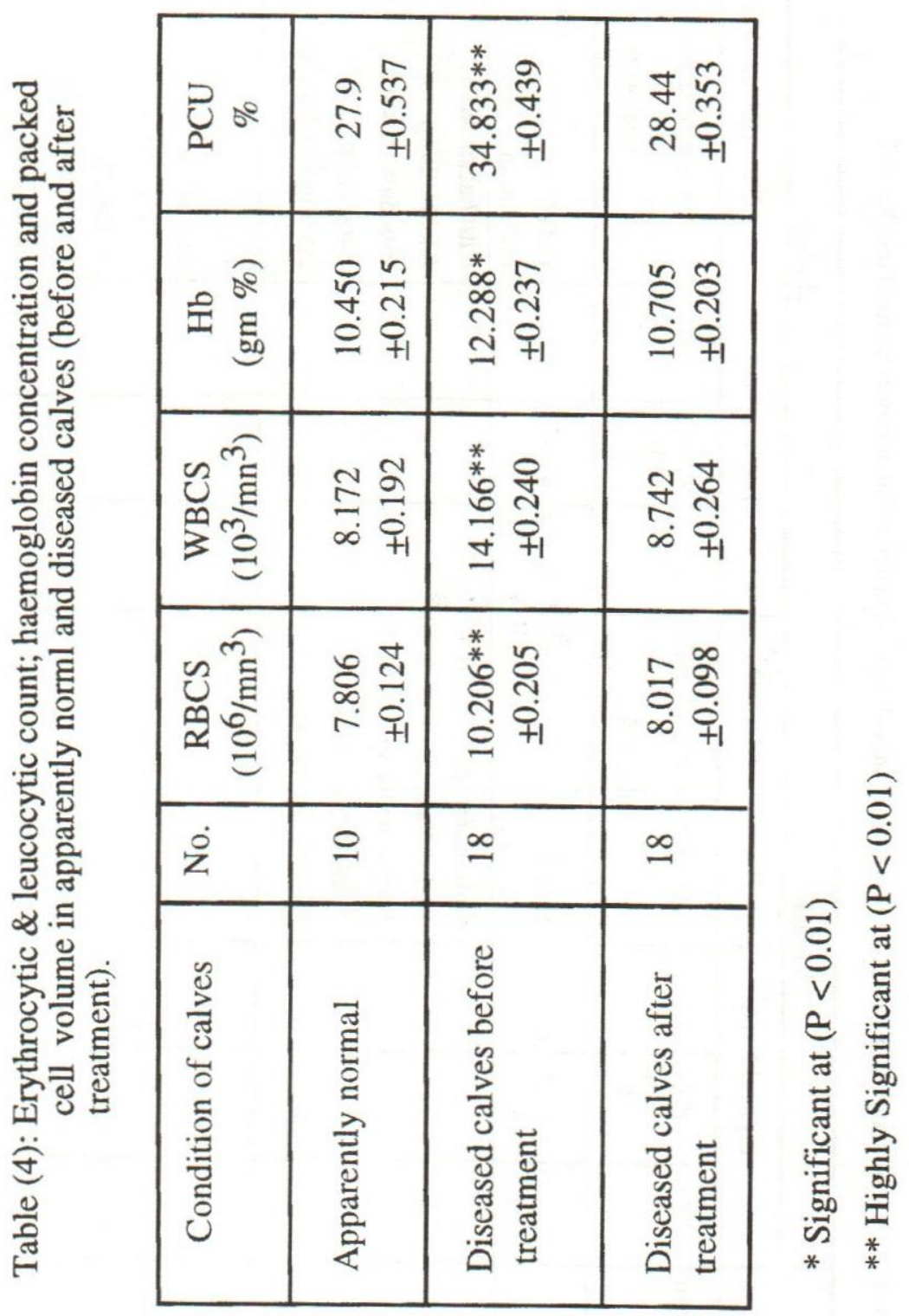

